The University of San Francisco

USF Scholarship: a digital repository @ Gleeson Library |

Geschke Center

Economics

College of Arts and Sciences

2002

\title{
How Efficient are Africa’s Emerging Stock Markets?
}

Magnus Arni Magnusson

Bruce Wydick

University of San Francisco,wydick@lucas.usfca.edu

Follow this and additional works at: http://repository.usfca.edu/econ

Part of the Economics Commons

\section{Recommended Citation}

Magnus Arni Magnusson And Bruce Wydick. How Efficient are Africa’s Emerging Stock Markets? Journal of Development Studies (April 2002), vol. 38, no. 4, pp.41-156. DOI: 10.1080/00220380412331322441

This Article is brought to you for free and open access by the College of Arts and Sciences at USF Scholarship: a digital repository @ Gleeson Library | Geschke Center. It has been accepted for inclusion in Economics by an authorized administrator of USF Scholarship: a digital repository @ Gleeson Library | Geschke Center. For more information, please contact repository@usfca.edu. 


\title{
How Efficient are Africa's Emerging Stock Markets?
}

\author{
MAGNUS ARNI MAGNUSSON and BRUCE WYDICK
}

The development of financial institutions has been viewed in recent years as critical to the economic development process. This research uses recent data from the eight largest African stock markets to test whether these markets meet the criterion of weak-form stock market efficiency with returns characterised by a random walk. Results are then compared with similar tests on emerging stock markets in Southeast Asia and Latin America. Conclusions from the research indicate that test results for weak-form efficiency in the emerging African stock markets compare favorably with those performed on other emerging stock markets.

\section{INTRODUCTION}

A broad consensus has emerged in recent decades emphasizing the critical role of financial systems in the process of economic development. Since the seminal work of McKinnon [1973], volumes of research have underscored the need for financial institutions to efficiently transfer capital from savings to productive investment. Our research contributes to this large body of literature by testing for weak-form efficiency in the emerging equity markets in Africa, and comparing these results with similar tests on a sample of other emerging stock markets in Asia and Latin America.

The increasing emphasis on the performance of financial systems in developing countries has arisen in the context of an increasingly liberalised and integrated global 
financial network. Financial flows to developing countries have soared as investors, seeking the diversification and often high expected returns associated with foreign investment, have eagerly channelled resources toward the new emerging stock markets.

The growth in stock markets in the emerging economies has reflected the increased demand for such transactions and the lower costs of investing in international markets. According to 1999 International Finance Corporation (IFC) statistics, from 1989-1998 the number of developing countries with actively trading stock markets increased from 31 to 78 , the number of domestic companies listed on emerging market stock indices rose over $300 \%$ from 8,709 to 26,354 , and market capitalisation in the emerging markets increased by $256 \%$ to US $\$ 1.91$ trillion.

The establishment of these equity markets in Africa and other developing regions is potentially beneficial for both developing economies and international investors. First, considerable evidence points to beneficial effects of well-functioning equity markets on the economic growth process in developing countries. ${ }^{1}$ Because of their greater wealth, investors in industrialised countries are in a better position to absorb the risk associated with investment projects in LDCs [Snowden, 1997]. Yet by bearing this risk, international investors can benefit by reaping the gains associated with high expected yields that have low correlations with existing investments in industrialised countries. ${ }^{2}$

Nevertheless, thin markets such as the emerging stock markets in Africa are often viewed as subject to manipulation by insiders at the expense of other investors. It is important, therefore, that stock markets in developing countries are able to pass as least the lowest hurdles of speculative efficiency. In Section II of this article, we briefly review the existing literature on tests of weak-form efficiency in emerging markets. In Section 
III we describe specific characteristics of the African markets in our study. We present in Section IV tests of weak-form efficiency on the emerging African stock markets, generally considered to be a minimal hurdle that a market must pass with respect to efficiency. As described in Section IV, weak-form efficiency, while not implying that a market cannot be exploited through inside information, does imply that systematic excess returns are not possible through exploitation of past movements in asset prices.

From our tests, we show in Section V that the emerging African stock markets actually fair quite well with regards to weak-form efficiency relative to our sample of emerging markets from Latin America and Asia. Our results for some of the newest African markets must be interpreted with some caution, since the data series available for the newest African markets is not as long as for the more-established markets. Yet preliminary evidence leads us to infer that six of the eight African markets are able to clear the lowest hurdle with regard to weak-form efficiency-non-predictability of market returns based on past returns. Moreover South Africa, Nigeria, Mauritius, Kenya, and Cote d'Ivoire clear a higher hurdle, presenting no evidence of predictability of market volatility based on past volatility. These findings compare well to our random sample of nine emerging stock markets in Latin America and Asia, where only five of nine markets are able to meet the first of these criteria, and only two, Brazil and Ecuador, meet the second. Section VI closes with conclusions and implications from our research.

\section{THE EFFICIENT MARKETS HYPOTHESIS AND PREVIOUS TESTING OF THE EMH IN DEVELOPING COUNTRIES}

For a stock market to be efficient, movements in prices of the market's underlying securities must be characterised by a random walk based on currently available 
information. From Fama [1970], the strong form of the efficient markets hypothesis states that an equity market efficiently converts all information into accurate security prices such that no information of any kind, public or private, will help investors achieve superior returns. The semi-strong form of the hypothesis states that equity markets accurately process all publicly available information. This renders techniques such as fundamental analysis, exploiting differences between discounted expected earnings and current prices, useless for predicting future returns. The weak form of the efficient markets hypothesis states that past stock market information is irrelevant for predicting future movements in stock prices.

Though no stock market is generally believed to be strong-form efficient, most early tests of stock markets in industrialised countries have typically been unable to reject null hypotheses of semi-strong and weak-form efficiency [Fama, 1970]. ${ }^{3}$ Some recent studies, however, have tested for weak-form efficiency in developing countries, focusing primarily on the emerging Asian economies, the Latin American markets, and the Middle East. Chan, Gup, and Pan [1992], for example, use unit root tests that show weak-form stock market efficiency in Hong Kong, South Korea, Singapore, and Taiwan. Liu, Song and Romilly [1997] find that both the Shanghai and Shenzhen Chinese stock market indices are characterised by a random walk and are thus weak-form efficient, although cointegration tests indicate joint inefficiency between the two markets, i.e. past returns from one market can be used to predict returns in another. Groenewold and Ariff [1998], carrying out unit-root tests on a set of ten stock markets in the Asia/Pacific region, find some evidence of violations of weak-form efficiency, yet they find the violations fairly mild in most markets. 
In a test on Latin American stock markets, Urrutia [1995] finds that these markets generally fail to pass tests of weak-form efficiency in that they do not follow a random walk. However, he finds them weak-form efficient by means of a runs test, implying that investors are unlikely to be able to develop trading strategies to earn excess returns. El-Erian and Kumar [1995] find some departures from weak-form efficiency in Middle Eastern stock markets, but emphasise the serial dependence is sufficiently weak that it likely has little value in predicting future prices. Their finding is consistent with that of Butler and Malaikah [1992], who find statistically significant autocorrelation in the stock markets of Kuwait and Saudi Arabia. In tests using 1976-92 data carried out on 20 emerging equity markets ${ }^{4}$ (including Nigeria and Zimbabwe), Claessens et al. [1995] find significant first-order autocorrelation in stock market returns in Chile, Columbia, Greece, Mexico, Pakistan, the Philippines, Portugal, Turkey, and Venezuela. They also find Ljung-Box Q-statistics reflecting significant autocorrelation to twelve lags for Chile, Columbia, Mexico, Pakistan, Greece and Zimbabwe.

Two pieces of research that focus specifically on African markets are Dickinson and Muragu [1994] and Olowe [1999]. Dickinson and Muragu create a database of weekly prices over ten years of the 30 most actively traded equities on the Nairobi Stock Exchange. They fail to find evidence inconsistent with weak-form efficiency in the stock exchange by means of both runs tests and Q-test statistics, but suggest that a number of studies must be carried out on any market using a variety of methodologies to draw firm conclusions about weak-form efficiency. Olowe [1999] carries out tests using monthly data on 59 randomly selected securities from 1981-92 on the Nigerian Stock Exchange. He finds the Nigerian market to conform to weak-form efficiency in joint Q-tests of 
partial autocorrelation coefficients for ten lags in the return data, though he argues that poor informational flows and inefficient communications systems cast doubts on the ability of the market to pass higher hurdles of efficiency.

\section{THE AFRICAN MARKETS}

Interest in emerging equity markets accelerated in the early 1980s, as investors became increasingly aware of the rapid growth of the Southeast Asian economies [Kuczynski, 1994]. Yet African markets have a history of neglect by international investors. They have frequently been hard to penetrate, located in war-torn regions, or in countries subject to sanctions (as was the case in South Africa). The African stock markets vary tremendously in their size, liquidity, and openness, yet most are thinly traded. Of the eight sub-Saharan markets analysed in this paper, only Nigeria, South Africa and Zimbabwe are not considered "frontier" markets, and are thus included in the IFC Global Composite Index.

The substantial variation in size between the African markets is readily seen in Table 1A, which gives 1998 IFC figures for the number of companies listed in each market, market capitalisation in U.S. dollars, and other measures of trading activity. The Johannesburg Stock Exchange in South Africa has more companies listed, and far greater market capitalization, than all the other markets combined, and is comparable to the data for the larger, more developed markets of Latin America and Asia seen in Table 1B. There is a very large step down to the second and third largest equity markets, those of Nigeria and Zimbabwe, which are then followed in size by Kenya, Mauritius, Cote d'Ivoire, Ghana, and Botswana, respectively. There are other very small sub-Saharan 
stock markets in Namibia, Swaziland, and Zambia, which are not analysed here because of their very small size and availability of data.

Returns in the major African stock markets during the 1990s were high, but very volatile. The IFC Nigerian stock market index, for example, showed an average gain of 26.4 percent through the ten years prior to 1999 . For Zimbabwe, the average yearly return was 16.8 percent during this period, while the more mature South African stock market yielded a more modest return of 12.3 percent [IFC, 1999]. The long-term high yields in markets such as Nigeria and Zimbabwe, however, come at the expense of nearly heart-stopping volatility: While the Zimbabwe index rose 143.8 percent during one year (in 1993), it plummeted by 59.8 percent during the previous year, 1992 and by 53.3 percent in 1997; while the yield on the Nigerian index was 190.9 percent in 1994 and 63.0 percent in 1996, the index registered declines of $34.9,20.9$, and 25.1 percent in 1992, 1995, and 1998 respectively. Yet the high returns over the long horizon have not remained unnoticed: At least twelve financial institutions had by 1996 created "Africa funds", with capitalisation of about \$US 1 billion, which solely target African markets [Mobius, 1996].

\section{DATA AND TESTING}

In carrying out tests for weak-form efficiency we use data from the IFC's Emerging Markets Data Base (EMDB), generally considered the most reliable and widely used indices of stock market activity for emerging stock markets. Raw market data is used by the IFC to form aggregate indices, created by IFC to be consistent across the 45 countries for which data is available, to eliminate inconsistencies that can arise between locally 
produced indices. Markets in the IFC index coverage constitute a subset of all stock markets in developing countries. These markets typically trade securities from at least 30 firms, have market capitalisations of US\$1 billion or more, and had an annual value traded of US $\$ 100$ million or more at the start of coverage.

We use monthly data for the eight African markets listed in the IFC index. Though serial correlation can clearly occur in periods shorter than one month, we follow previous studies such as Urrutia [1995] and Claessens et. al [1995] and use increments of one month as a base criterion for weak-form efficiency. In order to compare the efficiency of the African markets with stock markets in other developing countries, we also carry out the same tests on a sample of emerging stock markets in nine other developing countries in Latin America and Asia. These markets used as a basis for comparison with the African markets were randomly chosen, except for some consideration taken to include both some of the more established equity markets of Asia and Latin America as well as some less-mature markets. In this way, we can compare the African markets with established markets such as South Korea, Taiwan, Argentina, Brazil, Chile, and Mexico along with newer markets such as the Guayaquil Stock Exchange in Ecuador and the Asian markets in Thailand and Indonesia. Furthermore, as a benchmark of efficiency for the emerging markets, we perform the same tests on the U.S. stock market. Basic data for the African markets is given in Table 1A and for the comparison markets in Table 1B. The data series for each market varies between 26 and 145 months previous to 1998 , depending on the age of the market and data availability, and is given for each country separately in column one of Tables 2A and 2B. 
Campbell, Lo, and MacKinley [1997] categorise three successively stronger tests of random walk, a process that implies weak-form efficiency in time series data. The least restrictive of these categories is a Random Walk 3 (RW3). In a market that complies to RW3 it is not possible to use information on past prices to predict future prices, i.e. price movements of securities in a market conforming to RW3 have uncorrelated increments. A market conforming to RW3 is characterised by a random walk and is therefore weakform efficient. In such a market the absence of serial correlation in returns implies that prices are not being driven by insider manipulation or lack of investor liquidity over long periods. The test for RW3 implies looking at the Partial Auto-Correlation Function (PACF) of random increments of past price information on each market for up to $k$ lagged values, and examining if they are statistically different from zero. Weak-form efficiency implies that expected increases in the price of an asset should not exceed some normal return $\mu$ over the specified interval, or

$$
E\left[\Delta p_{t} \mid I_{t-1}\right]=\mu
$$

where $\Delta p(t)$ 's are incremental changes in log prices at time $t$, and $I_{t-l}$ represents the information set available to market participants at $t-1$. To satisfy weak-form efficiency in conforming to an RW3, future changes in the price of assets must be uncorrelated with past changes in prices. This yields a simple test of the null hypothesis that all $\gamma_{n}=0$ with an alternative hypothesis that $\gamma_{n} \neq 0$ in an estimation with $k$ lags on the dependent variable given by

$$
\Delta p_{t}=\mu+\sum_{n=1}^{k} \gamma_{t-n} \Delta p_{t-n}+\varepsilon_{t}
$$


where $\varepsilon_{t}$ is a random price innovation with mean equal to zero. (We set $k=4$, which is sufficient using monthly data). The Box-Pierce Q-statistic yields a joint test of the PACF coefficients for the existence of autocorrelation. However, the test of a market conforming to an RW3 imposes no further restrictions on the price increments at time $t$.

In an RW3, however, it may be possible to use information on the variance of past prices to predict future volatility of the market. Conforming to RW2 imposes an additional condition on (2), namely that the increments are independent and nonidentically distributed (INID). Thus a test for conforming to RW2 implies a test for RW3 plus a test to ascertain the correlation of squared incremental price changes. This means that the variance of the innovation tomorrow is unforecastable from past variances in the time series. If squared random increments of past price information in the market are not significantly different from zero, the market conforms to RW2 and it is not possible to predict future volatility by looking at past volatility. In an RW2 variance can change over time (may be heteroskedastic), but it must change over time in an unpredictable manner.

If a market conforms to the random walk characteristic of an RW1, it is neither possible to predict future price movements nor future volatility by examining information on past prices. But in an RW1, random price increments can also be described as white noise, and independent and identically distributed (IID). A test for RW1 implies a test for heteroskedasticity in the historical time series of price innovations. An RW1 imposes a much heavier restriction on innovations in security prices; it is generally thought to characterise only the most mature and efficient equity markets. To test whether individual markets conform to RW1, we thus use the White test for heteroskedasticity. 


\section{ESTIMATION RESULTS}

The results of the estimations, presented in Table 2A, indicate a surprising degree of efficiency in the emerging African stock markets. For markets in Botswana, Cote d'Ivoire, Kenya, Mauritius, and South Africa the hypothesis that equity markets are characterised by a random walk of RW3 cannot be rejected, indicating that these markets pass at least the lowest (but very significant) hurdle of weak-form efficiency when tests are carried out in data measured in local currency. Nevertheless, tests for conformation to RW3 are rejected at the 95 percent level in Ghana, Nigeria and Zimbabwe.

Foreign speculators and local investors, however, may be less interested in nominal fluctuations in these markets when they are measured in the local currency than when they are measured in real values, which might be more appropriately measured in U.S. dollars. It is also possible that inflation and devaluation of the local African currency with respect to the U.S. dollar could skew the results of tests using local currency values. Therefore tests on the data were also carried out in U.S. dollars. Carrying out the tests in U.S. dollars produces no change in results for those African markets that conformed to an RW3, nor for Ghana and Zimbabwe which do not. However, for Nigeria, which during the sample period experienced both significant inflationary pressures and a large inflow of dollars from oil exports, the results do change. In tests using U.S. dollars, the Nigerian stock market conforms to an RW3 at the 95 percent confidence level, and we thus provide results of the test for Nigeria in U.S. dollars in Table 2A.

The six markets that conform to an RW3 we then test to see if they conform to the higher weak-form efficiency standard of an RW2. We find the results astonishing. Only a 
solitary market, Botswana, fails this second test. Returns in Cote d'Ivoire, Kenya, Mauritius, Nigeria (in U.S. dollars) and South Africa all confirm to an RW2. For these markets, even future volatility is unforecastable from past volatility. We then carry out the White test for heteroskedasticity on the remaining five markets. As with the Latin American and Asian markets in our study, none of the African markets is able to conform to an RW1, the most restrictive level of weak-form efficiency. In our sample, it is only the US market that is able to conform to an RW1.

Yet the results from the African markets are unexpected and encouraging, especially as they are compared to the test results in the other developing countries that are typically believed to be farther along the path of institutional development. Among the nine emerging markets in Latin America and Asia used for comparison, only three markets (South Korea, Taiwan, and Ecuador) conform to an RW3 with tests carried out in local currency. When the heavily inflationary economies (during the sample period) of Brazil and Argentina are analysed in U.S. dollars, these markets also conform to an RW3. But of the five markets that conform to an RW3, only the Ecuadorian and Brazilian markets also conform to an RW2; in all other markets it is possible to use past market volatility to predict future volatility. As mentioned previously, none of the Asian and Latin American markets in the study conforms to an RW1 since even the Ecuadorian and Brazilian markets display heteroskedastic price movements over time.

A comparison of the tests for weak-form efficiency of the African markets and the other markets included in the study is revealing. It is true that the African markets are unable to match the efficiency of the U.S. stock market. As seen in Table 2B the U.S. market easily conforms to an RW3 and an RW2, and conforms to an RW1 at a $90 \%$ level 
of confidence. We would expect such findings, however, from what is generally considered the most efficient stock market in the world. However, the comparison of the African markets with those in the other developing regions is more interesting. Despite the vastly greater capital flows to the Latin American and Southeast Asian equity markets, efficiency in the African stock markets compares quite favourably with those in the other major regions of the developing world. The findings presented here show that the African markets certainly fare no worse in terms of weak-form efficiency than all but the most mature markets in these other regions.

It is important to clarify that our results are based on a relatively small (four-year) time series for three of the eight African markets (Cote d'Ivoire, Kenya, Mauritius) and one non-African market (Ecuador). A short time series may bias tests against rejecting weak-form efficiency. Of the three African markets with short time series, we feel that, based on $p$-values, our results for Kenya (and possibly Mauritius) could reject weak-form efficiency in the form of RW3 with the addition of several more years of data.

However, it appears that our fundamental result, that African markets perform comparatively well in terms of weak-form efficiency to markets in other LDCs, is quite robust to changes in length of data series. As a diagnostic, we ran tests for each market based only on the last four years of data for each market. In these tests, of the eight African markets only Ghana rejected the hypothesis of RW1 weak-form efficiency, while among the nine comparison stock markets, both Mexico and Indonesia rejected RW1 efficiency (at the 10 percent level). In tests for RW2 weak-form efficiency using the same data interval, only two of eight African markets rejected conformity to an RW2, while four of nine of the comparison markets in Latin America and Asia rejected 
hypotheses of weak-form efficiency at the RW2 level. Such results suggest that the African markets may have made greater strides in the development of efficient financial institutions than previously believed.

\section{CONCLUSION}

A number of recent studies have shown a strong correlation between the development of equity markets in developing countries and economic growth. However, for both investors and developing economies to gain from equity financing of investment in developing countries, it is important that equity markets, along with all financial institutions, pass at least minimal hurdles of efficiency.

The results from this study show six of our eight African stock markets studied pass the basic hurdles of weak-form efficiency, that past movements in stock prices cannot be used to predict future movements in prices. ${ }^{5}$ The results from our tests do not show African markets passing the same high hurdles of efficiency as, for example, the U.S. stock market. Nevertheless, the results of our research present evidence which appears to undermine the stereotype of African markets as perhaps more subject to manipulation than the equity markets of the emerging Asian and Latin American economies.

The fact that several of the developing country markets were able to pass different hurdles of efficiency when returns are measured in U.S. dollars could indicate that the investors creating efficiency in these markets are international investors. It is possible therefore that one important role of international investors may be to establish a discipline in emerging equity markets that is able to dissuade attempts at market manipulation by 
domestic insiders. An interesting question for future research might entail an investigation of the role of capital controls and exchange rate regimes on maintaining efficiency in stock markets in developing countries.

It is important to clarify caveats and qualifications for our findings. First, as mentioned previously, some of the African stock markets are quite young and do not have a long time series of data from which to carry out weak-form efficiency tests. Our results for the three newest African markets should be taken as best estimates given the present availability of data, while understanding that longer data series for these new markets will lead to stronger tests for their efficiency. But as we show in Section V, the basic findings of the research do appear to be robust to differences in time series length.

Secondly, it is important to remember that this study focuses only on weak-form efficiency, i.e. that information on past asset prices cannot be used to earn abnormal returns in the market. It is possible that the better-researched markets in Latin America and Asia may be more able to pass tests for semi-strong efficiency, which dictates that public knowledge cannot be utilised to earn supra-normal returns. However, it is unlikely that any of these markets would fair well in tests for strong-form efficiency; private information exploited by insiders is highly likely to yield supra-normal returns, especially in emerging markets. It is important, nevertheless, that instances of insider trading be kept to a minimum in emerging stock markets, an issue that is more directly related to an internal willingness and ability to police corruption in public institutions.

Finally, although many previous studies have also used monthly data, it is possible that using different-sized data intervals could yield different results. In general, the shorter the time units of measurement, the more likely positive serial correlation is to be 
found in stock market data. Negative serial correlation, on the other hand, is more likely to be uncovered in longer units of observations. For example, U.S. market indices such as the Dow Jones index have been found to be mean-reverting over long horizons, such that after three or four years of upward movement, a future decline is more likely than a continuous boom [De Bondt, 1991]. However, we view monthly data as a good minimal test for weak-form efficiency, and furthermore the strength of our results lies in the comparison of the African markets with other developed and less-developed markets using a standard time-unit of analysis.

Taking these caveats into account, however, we see these results as indicative that African stock markets, as institutional building blocks for development, may not lag as far behind their Asian and Latin American counterparts as perhaps has been commonly believed. In a hopeful scenario, these financial markets will develop such that they are able to become important conduits for large volumes of capital from investors in industrialised nations, who can more easily bear the risks associated with new investment in developing countries. In addition, strong equity markets can provide an efficient outlet for savings for the small, but growing, middle and upper classes in the African nations, who may have previously directed savings to equity markets in industrialised countries. 


\section{Notes}

Magnus Arni Magnusson: Cambridge University; Bruce Wydick: University of San Francisco. We wish to thank Michael Kevane, Tetteh Kofi, two anonymous referees, and especially John Veitch for helpful comments and suggestions. Financial support from the Pew Charitable Trust Evangelical Scholars Program is gratefully acknowledged. Errors are all the responsibility of the authors.

${ }^{1}$ For example, Atje and Iovanovic [1993] find in an empirical study of 40 countries that there exists a significant correlation between GDP growth and stock market activity. Obstfeld [1994] develops a model that shows how international investment increases overall economic growth and welfare through a reduction in aggregate portfolio risk. Finally, Levine and Zervos [1998] carry out empirical tests that show a correlation between stock market liquidity and increases in capital accumulation, productivity, and GDP.

${ }^{2}$ Claessens [1995] points out that the benefits of diversification are much stronger across international financial markets than within a domestic market. Bekaert and Harvey [1995] note one reason returns in emerging markets may have a low or negative correlation with existing portfolios is that the industry mix in such countries is likely to be much different from the average world mix. Some such as Errunza et. al. [1999] argue that much international diversification can be achieved by holding assets that are traded on U.S. domestic markets, yet empirical work by Harvey [1993] shows that by investing up to $20 \%$ of an international portfolio in emerging markets, statistically significant Pareto improvements are possible in the risk-return trade-off.

${ }^{3}$ Some important later work, however, has cast some degree of doubt over these initial findings: French and Roll [1984] suggest that markets may overreact to new information. Lo and MacKinlay [1988], find small degrees of positive serial correlation in U.S. stock prices. This work has called into question whether markets strictly meet the criteria of semi-strong and weak-form market efficiency, respectively. Still the belief is generally held that any inefficiencies in U.S. stock markets are so small that they do not leave the market open to exploitation in any systematic way [Fama, 1991; Malkiel, 1996].

${ }^{4}$ The twenty stock markets covered in the study of Claessens, Dasgupta, and Glen included Argentina, Brazil, Chile, Colombia, Greece, India, Indonesia, Jordan, South Korea, Malaysia, Mexico, Nigeria, Pakistan, Philppines, Portugal, Taiwan, Thailand, Turkey, Venezuela, and Zimbabwe.

${ }^{5}$ It is worth mentioning that we carried out tests on the predictability of individual market returns as a function of past returns in the countries own market and of past returns in neighboring markets. We found no statistically significance from past returns in other countries' markets on predicting future returns in any of the markets tested. 
TABLE 1A

BASIC DATA: AfricAN STOCK MARKETS, 1998

\begin{tabular}{|l|r|r|r|r|r|}
\hline $\begin{array}{l}\text { African } \\
\text { Market }\end{array}$ & $\begin{array}{l}\text { Number of } \\
\text { Firms 1998 }\end{array}$ & $\begin{array}{l}\text { Market } \\
\text { Capitalisation } \\
\text { (\$US millions) }\end{array}$ & $\begin{array}{l}\text { Value traded } \\
\text { (\$US millions.) }\end{array}$ & $\begin{array}{l}\text { Avg. Index } \\
\text { Turnover } \\
\text { Ratio }\end{array}$ & $\begin{array}{l}\text { Growth } \\
\text { 1989-98 }\end{array}$ \\
\hline Botswana & 14 & 724 & 70 & $10.5 \%$ & N/A \\
\hline Cote d'Ivoire & 35 & 1818 & 39 & $2.5 \%$ & N/A \\
\hline Ghana & 21 & 1384 & 60 & $4.8 \%$ & N/A \\
\hline Kenya & 58 & 2024 & 79 & $4.1 \%$ & N/A \\
\hline Mauritius & 40 & 1849 & 102 & $5.8 \%$ & N/A \\
\hline Nigeria & 186 & 2887 & 161 & $4.9 \%$ & $26.4 \%$ \\
\hline South Africa & 668 & 170,252 & 58,444 & $29.1 \%$ & $12.3 \%$ \\
\hline Zimbabwe & 67 & 1310 & 166 & $10.1 \%$ & $29.4 \%$ \\
\hline
\end{tabular}

TABLE 1B

BASIC DATA: LATIN AMERICAN AND ASIAN MARKETS Plus US STOCK MARKET, 1998

\begin{tabular}{|l|r|l|r|r|r|}
\hline Market & $\begin{array}{l}\text { Number } \\
\text { of Firms } \\
\mathbf{1 9 9 8}\end{array}$ & $\begin{array}{l}\text { Market } \\
\text { Capitalisation } \\
\text { (\$US millions) }\end{array}$ & $\begin{array}{l}\text { Value traded } \\
\text { (\$US mil.) }\end{array}$ & $\begin{array}{l}\text { Turnover } \\
\text { Ratio }\end{array}$ & $\begin{array}{l}\text { Avg. Index } \\
\text { Growth } \\
\mathbf{1 9 8 9 - 9 8}\end{array}$ \\
\hline Latin America & & & & & \\
\hline Argentina & 130 & 54,091 & 15,078 & $27.8 \%$ & $4.3 \%$ \\
\hline Brazil & 527 & 238,524 & 146,594 & $61.4 \%$ & $31.2 \%$ \\
\hline Chile & 277 & 62,682 & 4,419 & $7.1 \%$ & $25.0 \%$ \\
\hline Ecuador & 37 & 2,096 & 136 & $6.5 \%$ & $\mathrm{~N} / \mathrm{A}$ \\
\hline Mexico & 194 & 132,803 & 33,841 & $25.5 \%$ & $24.5 \%$ \\
\hline Asia & & & & & $-1.7 \%$ \\
\hline Indonesia & 287 & 22,104 & 9,709 & $43.9 \%$ & $2.1 \%$ \\
\hline Korea & 748 & 114,593 & 137,859 & $120.3 \%$ & $11.3 \%$ \\
\hline Taiwan & 437 & 260,015 & 884,698 & $340.2 \%$ & $-14.6 \%$ \\
\hline Thailand & 418 & 34,903 & 20,734 & $59.4 \%$ & $-19.76 \%$ \\
\hline & & & & & \\
\hline United States & 8450 & $13,451,352$ & $13,148,480$ & $97.6 \%$ & 19.76 \\
\hline
\end{tabular}


TABLE 2A

TESTS FOR WEAK-FORM EFFICIENCY: AFRICAN MARKETS

\begin{tabular}{|c|c|c|c|c|c|c|c|c|c|c|c|}
\hline \multirow{2}{*}{$\begin{array}{l}\text { Market/Lag } \\
\text { (Observations) }\end{array}$} & \multicolumn{4}{|c|}{ Partial Autocorr. Test for RW3 } & \multicolumn{4}{|c|}{ Partial Autocorr. Test for RW2 } & \multicolumn{3}{|c|}{ White Test for RW1 } \\
\hline & $\mathrm{AC}$ & PAC & Q-Stat & Prob. & $\mathrm{AC}$ & PAC & Q-Stat & Prob. & $\mathrm{R}^{2}$ & F-stat & Prob \\
\hline \multicolumn{12}{|l|}{ Botswana (71) } \\
\hline 1 & -0.162 & -0.162 & 1.953 & 0.162 & 0.467 & 0.467 & 16.173 & 0.000 & & & \\
\hline 2 & 0.088 & 0.064 & 2.541 & 0.281 & -0.034 & -0.323 & 16.260 & 0.000 & & & \\
\hline 3 & 0.100 & 0.128 & 3.304 & 0.347 & -0.025 & 0.210 & 16.307 & 0.001 & & & \\
\hline 4 & 0.056 & 0.090 & 3.549 & 0.470 & -0.010 & -0.159 & 16.315 & 0.003 & & & \\
\hline \multicolumn{12}{|c|}{ Cote d'Ivoire (48) } \\
\hline 1 & -0.019 & -0.019 & .0179 & 0.894 & -0.023 & -0.023 & 0.028 & 0.867 & 0.001 & 0.015 & 0.900 \\
\hline 2 & 0.042 & 0.042 & .1093 & 0.947 & -0.019 & -0.020 & 0.047 & 0.977 & & & \\
\hline 3 & -0.023 & -0.021 & .1370 & 0.987 & -0.024 & -0.025 & 0.0783 & 0.994 & & & \\
\hline 4 & -0.043 & -0.046 & .2385 & 0.993 & -0.024 & -0.026 & 0.1106 & 0.999 & & & \\
\hline \multicolumn{12}{|l|}{ Ghana (82) } \\
\hline 1 & 0.304 & 0.304 & 8.0337 & 0.005 & & & & & & & \\
\hline 2 & -0.003 & -0.105 & 8.0347 & 0.018 & & & & & & & \\
\hline 3 & -0.066 & -0.037 & 8.4228 & 0.038 & & & & & & & \\
\hline 4 & 0.187 & 0.245 & 11.571 & 0.021 & & & & & & & \\
\hline \multicolumn{12}{|l|}{ Kenya (48) } \\
\hline 1 & 0.120 & 0.120 & 0.731 & 0.392 & -0.066 & -0.066 & 0.223 & 0.636 & 0.014 & 0.655 & 0.422 \\
\hline 2 & -0.189 & -0.206 & 2.590 & 0.274 & -0.073 & -0.078 & 0.502 & 0.778 & & & \\
\hline 3 & -0.222 & -0.180 & 5.218 & 0.156 & -0.044 & -0.055 & 0.606 & 0.895 & & & \\
\hline 4 & 0.086 & 0.107 & 5.623 & 0.229 & -0.163 & -0.179 & 2.063 & 0.724 & & & \\
\hline \multicolumn{12}{|l|}{ Mauritius (48) } \\
\hline 1 & 0.103 & 0.103 & 0.545 & 0.460 & -0.165 & -0.165 & 1.382 & 0.240 & 0.010 & 0.489 & 0.483 \\
\hline 2 & -0.161 & -0.173 & 1.891 & 0.388 & 0.178 & 0.155 & 3.030 & 0.220 & & & \\
\hline 3 & 0.097 & 0.140 & 2.390 & 0.495 & -0.040 & 0.010 & 3.117 & 0.374 & & & \\
\hline 4 & 0.066 & 0.008 & 2.631 & 0.621 & -0.059 & -0.095 & 3.305 & 0.508 & & & \\
\hline \multicolumn{12}{|l|}{ Nigeria* (145) } \\
\hline 1 & -0.008 & -0.008 & 0.009 & 0.926 & -0.020 & -0.020 & 0.056 & 0.812 & 0.003 & 0.219 & 0.803 \\
\hline 2 & -0.062 & -0.062 & 0.586 & 0.746 & -0.018 & -0.018 & 0.104 & 0.949 & & & \\
\hline 3 & -0.095 & -0.096 & 1.930 & 0.587 & -0.009 & -0.009 & 0.115 & 0.990 & & & \\
\hline 4 & -0.071 & -0.078 & 2.697 & 0.610 & -0.007 & -0.07 & 0.122 & 0.998 & & & \\
\hline \multicolumn{12}{|c|}{ South Africa $(84)$} \\
\hline 1 & 0.007 & 0.007 & 0.005 & 0.944 & -0.031 & -0.031 & 0.082 & 0.775 & 0.000 & 0.004 & 0.946 \\
\hline 2 & -0.038 & -0.038 & 0.132 & 0.936 & 0.178 & 0.177 & 2.881 & 0.237 & & & \\
\hline 3 & 0.051 & 0.051 & 0.361 & 0.948 & -0.003 & 0.007 & 2.882 & 0.410 & & & \\
\hline 4 & -0.135 & -0.138 & 2.010 & 0.734 & 0.017 & -0.015 & 2.908 & 0.573 & & & \\
\hline \multicolumn{12}{|c|}{ Zimbabwe (145) } \\
\hline 1 & 0.393 & 0.393 & 22.86 & 0.000 & & & & & & & \\
\hline 2 & 0.239 & 0.100 & 31.38 & 0.000 & & & & & & & \\
\hline 3 & 0.392 & 0.320 & 54.41 & 0.000 & & & & & & & \\
\hline 4 & 0.233 & -0.021 & 62.59 & 0.000 & & & & & & & \\
\hline
\end{tabular}

* tests in U.S. dollars 
TABLE 2B

TESTS FOR WEAK-FORM EFFICIENCY: LATIN AMERICAN, ASIAN MARKETS AND US STOCK MARKET, 1998

\begin{tabular}{|c|c|c|c|c|c|c|c|c|c|c|c|}
\hline Market/Lag & \multicolumn{4}{|c|}{ Partial Autocorr. Test for RW3 } & \multicolumn{4}{|c|}{ Partial Autocorr. Test for RW2 } & \multicolumn{3}{|c|}{ White Test for RW1 } \\
\hline (Observations) & $\mathrm{AC}$ & PAC & Q-Stat & Prob. & $\mathrm{AC}$ & PAC & Q-Stat & Prob. & $\mathrm{R}^{2}$ & F-stat & Prob \\
\hline \multicolumn{12}{|l|}{$\begin{array}{l}\text { Argentina* } \\
\text { (145) }\end{array}$} \\
\hline 1 & -0.138 & -0.138 & 2.816 & 0.093 & 0.434 & 0.434 & 27.91 & 0.000 & & & \\
\hline 2 & -0.107 & -0.129 & 4.528 & 0.104 & 0.199 & 0.013 & 33.81 & 0.000 & & & \\
\hline 3 & 0.125 & 0.094 & 6.866 & 0.076 & 0.145 & 0.067 & 36.97 & 0.000 & & & \\
\hline 4 & -0.131 & -0.118 & 9.467 & 0.050 & 0.071 & -0.021 & 37.73 & 0.000 & & & \\
\hline \multicolumn{12}{|l|}{ Brazil* (98) } \\
\hline 1 & -0.138 & -0.138 & 1.912 & 0.167 & 0.162 & 0.162 & 2.649 & 0.104 & 0.008 & 0.397 & 0.672 \\
\hline 2 & 0.055 & 0.037 & 2.222 & 0.329 & 0.103 & 0.079 & 3.725 & 0.155 & & & \\
\hline 3 & 0.004 & 0.017 & 2.224 & 0.527 & 0.012 & -0.017 & 3.739 & 0.291 & & & \\
\hline 4 & -0.119 & -0.121 & 3.709 & 0.447 & 0.024 & 0.017 & 3.800 & 0.434 & & & \\
\hline \multicolumn{12}{|l|}{ Chile (145) } \\
\hline 1 & 0.337 & 0.337 & 16.85 & 0.000 & & & & & & & \\
\hline 2 & -0.051 & -0.186 & 17.24 & 0.000 & & & & & & & \\
\hline 3 & -0.084 & 0.0000 & 18.29 & 0.000 & & & & & & & \\
\hline 4 & -0.109 & -0.099 & 20.07 & 0.000 & & & & & & & \\
\hline \multicolumn{12}{|l|}{ Ecuador (48) } \\
\hline 1 & 0.028 & 0.028 & 0.039 & 0.843 & -0.001 & -0.001 & -0.001 & 0.994 & 0.002 & 0.093 & 0.760 \\
\hline 2 & 0.141 & 0.141 & 1.082 & 0.582 & 0.038 & 0.038 & 0.074 & 0.963 & & & \\
\hline 3 & -0.115 & -0.125 & 1.790 & 0.617 & -0.027 & -0.027 & 0.114 & 0.990 & & & \\
\hline 4 & -0.001 & -0.013 & 1.790 & 0.774 & -0.022 & -0.024 & 0.142 & 0.998 & & & \\
\hline \multicolumn{12}{|l|}{$\operatorname{Mexico}(145)$} \\
\hline 1 & -0.187 & -0.187 & 5.155 & 0.023 & & & & & & & \\
\hline 2 & 0.090 & 0.057 & 6.351 & 0.042 & & & & & & & \\
\hline 3 & 0.025 & 0.053 & 6.444 & 0.092 & & & & & & & \\
\hline 4 & -0.156 & -0.154 & 10.135 & 0.038 & & & & & & & \\
\hline \multicolumn{12}{|l|}{ Indonesia (98) } \\
\hline 1 & 0.277 & 0.277 & 7.759 & 0.005 & & & & & & & \\
\hline 2 & 0.124 & 0.051 & 9.318 & 0.009 & & & & & & & \\
\hline 3 & 0.062 & 0.017 & 9.715 & 0.021 & & & & & & & \\
\hline 4 & 0.144 & 0.127 & 11.86 & 0.018 & & & & & & & \\
\hline \multicolumn{12}{|l|}{ Korea (266) } \\
\hline 1 & 0.039 & 0.039 & 0.416 & 0.519 & 0.430 & 0.430 & 49.77 & 0.000 & & & \\
\hline 2 & 0.069 & 0.068 & 1.717 & 0.424 & 0.302 & 0.144 & 74.42 & 0.000 & & & \\
\hline 3 & -0.021 & -0.026 & 1.832 & 0.608 & 0.203 & 0.037 & 85.56 & 0.000 & & & \\
\hline 4 & 0.005 & 0.002 & 1.838 & 0.766 & 0.004 & -0.156 & 85.56 & 0.000 & & & \\
\hline \multicolumn{12}{|l|}{ Taiwan (158) } \\
\hline 1 & 0.053 & 0.053 & 0.446 & 0.504 & 0.281 & 0.281 & 12.66 & 0.000 & & & \\
\hline 2 & 0.046 & 0.043 & 0.787 & 0.675 & 0.295 & 0.235 & 26.77 & 0.000 & & & \\
\hline 3 & -0.045 & -0.050 & 1.116 & 0.773 & 0.181 & 0.059 & 32.10 & 0.000 & & & \\
\hline 4 & 0.018 & 0.021 & 1.167 & 0.884 & 0.115 & -0.004 & 34.28 & 0.000 & & & \\
\hline \multicolumn{12}{|l|}{ Thailand(266) } \\
\hline 1 & 0.096 & 0.096 & 2.472 & 0.116 & & & & & & & \\
\hline 2 & 0.199 & 0.192 & 3.167 & 0.001 & & & & & & & \\
\hline 3 & -0.006 & -0.041 & 13.17 & 0.004 & & & & & & & \\
\hline 4 & -0.005 & -0.041 & 13.18 & 0.010 & & & & & & & \\
\hline \multicolumn{12}{|l|}{ U.S. (266) } \\
\hline 1 & -0.025 & -0.025 & 0.172 & 0.678 & 0.030 & 0.030 & 0.245 & 0.621 & 0.053 & 2.701 & 0.069 \\
\hline 2 & -0.030 & -0.031 & 0.417 & 0.812 & 0.036 & 0.036 & 0.603 & 0.740 & & & \\
\hline 3 & -0.070 & -0.072 & 1.740 & 0.628 & 0.025 & 0.023 & 0.773 & 0.856 & & & \\
\hline 4 & -0.057 & -0.062 & 2.633 & 0.621 & 0.003 & 0.000 & 0.775 & 0.942 & & & \\
\hline
\end{tabular}


TABLE 3

SUMMARY OF TESTS FOR WEAK-FORM EFFICIENCY

\begin{tabular}{|c|c|c|c|c|}
\hline$\frac{\text { AFRICAN }}{\text { MARKETS: }}$ & $\begin{array}{l}\text { Conform to RW3? } \\
\text { (uncorr'd price } \\
\text { movements) }\end{array}$ & $\begin{array}{l}\text { Conform to } \\
\text { RW2? (INID price } \\
\text { movements) }\end{array}$ & $\begin{array}{l}\text { Conform to } \\
\text { RW1? (IID price } \\
\text { movements) }\end{array}$ & $\begin{array}{l}\text { Inference for Weak-Form } \\
\text { Market Efficiency: }\end{array}$ \\
\hline Botswana & YES & $\mathrm{NO}$ & $\mathrm{NO}$ & $\begin{array}{l}\text { RW3 not rejected; } \\
\text { RW1 and RW2 rejected }\end{array}$ \\
\hline Cote d'Ivoire & YES & YES & $\mathrm{NO}$ & $\begin{array}{l}\text { RW2 and RW3 not rejected; } \\
\text { RW1 rejected. }\end{array}$ \\
\hline Ghana & $\mathrm{NO}$ & $\mathrm{NO}$ & $\mathrm{NO}$ & $\begin{array}{l}\text { All Tests for Weak-form } \\
\text { Efficiency Rejected. }\end{array}$ \\
\hline Ghana (\$US) & $\mathrm{NO}$ & $\mathrm{NO}$ & $\mathrm{NO}$ & $\begin{array}{l}\text { All Tests for Weak-form } \\
\text { Efficiency Rejected. }\end{array}$ \\
\hline Kenya & YES & YES & $\mathrm{NO}$ & $\begin{array}{l}\text { RW2 and RW3 not rejected; } \\
\text { RW1 rejected. }\end{array}$ \\
\hline Mauritius & YES & YES & $\mathrm{NO}$ & $\begin{array}{l}\text { RW2 and RW3 not rejected; } \\
\text { RW1 rejected. }\end{array}$ \\
\hline Nigeria & $\mathrm{NO}$ & NO & $\mathrm{NO}$ & $\begin{array}{l}\text { All Tests for Weak-form } \\
\text { Efficiency Rejected. }\end{array}$ \\
\hline Nigeria (\$US) & YES & YES & $\mathrm{NO}$ & $\begin{array}{l}\text { RW2 and RW3 not rejected; } \\
\text { RW1 rejected. }\end{array}$ \\
\hline South Africa & YES & YES & $\mathrm{NO}$ & $\begin{array}{l}\text { RW2 and RW3 not rejected; } \\
\text { RW1 rejected. }\end{array}$ \\
\hline Zimbabwe & NO & NO & NO & $\begin{array}{l}\text { All Tests for Weak-form } \\
\text { Efficiency Rejected. }\end{array}$ \\
\hline $\begin{array}{l}\text { Zimbabwe } \\
\text { (\$US) }\end{array}$ & NO & NO & NO & $\begin{array}{l}\text { All Tests for Weak-form } \\
\text { Efficiency Rejected. }\end{array}$ \\
\hline \multicolumn{5}{|c|}{ LATIN AMERICA: } \\
\hline Argentina & $\mathrm{NO}$ & $\mathrm{NO}$ & $\mathrm{NO}$ & $\begin{array}{l}\text { All Tests for Weak-form } \\
\text { Efficiency Rejected. }\end{array}$ \\
\hline Argentina (\$US) & YES & $\mathrm{NO}$ & $\mathrm{NO}$ & $\begin{array}{l}\text { RW3 not rejected; } \\
\text { RW1 and RW2 rejected }\end{array}$ \\
\hline Brazil & $\mathrm{NO}$ & $\mathrm{NO}$ & $\mathrm{NO}$ & $\begin{array}{l}\text { All Tests for Weak-form } \\
\text { Efficiency Rejected. }\end{array}$ \\
\hline Brazil (\$US) & YES & YES & $\mathrm{NO}$ & $\begin{array}{l}\text { RW2 and RW3 not rejected; } \\
\text { RW1 rejected. }\end{array}$ \\
\hline Chile & $\mathrm{NO}$ & $\mathrm{NO}$ & $\mathrm{NO}$ & $\begin{array}{l}\text { All Tests for Weak-form } \\
\text { Efficiency Rejected. }\end{array}$ \\
\hline Ecuador & YES & YES & $\mathrm{NO}$ & $\begin{array}{l}\text { RW1 rejected, RW2 not } \\
\text { rejected }\end{array}$ \\
\hline Mexico & $\mathrm{NO}$ & $\mathrm{NO}$ & $\mathrm{NO}$ & $\begin{array}{l}\text { All Tests for Weak-form } \\
\text { Efficiency Rejected. }\end{array}$ \\
\hline \multicolumn{5}{|l|}{ ASIA: } \\
\hline$\overline{\text { Indonesia }}$ & $\mathrm{NO}$ & NO & $\mathrm{NO}$ & $\begin{array}{l}\text { All Tests for Weak-form } \\
\text { Efficiency Rejected. }\end{array}$ \\
\hline Korea & YES & $\mathrm{NO}$ & $\mathrm{NO}$ & $\begin{array}{l}\text { RW3 not rejected; } \\
\text { RW1 and RW2 rejected }\end{array}$ \\
\hline Taiwan & YES & $\mathrm{NO}$ & $\mathrm{NO}$ & $\begin{array}{l}\text { RW3 not rejected; } \\
\text { RW1 and RW2 rejected }\end{array}$ \\
\hline Thailand & $\mathrm{NO}$ & $\mathrm{NO}$ & $\mathrm{NO}$ & $\begin{array}{l}\text { All Tests for Weak-form } \\
\text { Efficiency Rejected. }\end{array}$ \\
\hline \multicolumn{5}{|l|}{ US MARKET: } \\
\hline United States & YES & YES & YES & $\begin{array}{l}\text { RW1, RW2, and RW3 } \\
\text { Not Rejected }\end{array}$ \\
\hline
\end{tabular}




\section{REFERENCES}

Atje, R., and B. Jovanovic, 1993, 'Stock Markets and Development', European Economic Review, Vol.37, No.2, pp.632-40.

Bekaert, G. and Campbell R.H., 1995, 'Rime-Varying World Market Integration', Journal of Finance, Vol.50, No.2, pp.403-44.

Butler, K.C., and S.J. Malaikah, 1992, 'Efficiency and Inefficiency in Thinly Traded Stock Markets: Kuwait and Saudi Arabia', Journal of Banking and Finance, Vol.16, No.2, pp.197-210.

Campbell, J.Y., A.W. Lo, and A. Craig MacKinley. 1997, The Econometrics of Financial Markets, Princeton: Princeton University Press.

Chan, K.C., B.E. Gup, and Ming-Shiun Pan, 1992, 'An Empirical Analysis of Stock Prices in Major Asian Markets and the United States', The Financial Review, Vol.27, No.2, pp.289-307.

Claessens, S., 1995, The Emergence of Equity Investment in Developing Countries: Overview', The World Bank Economic Review, Vol.9, No.1, pp.1-17.

Claessens, S., S. Dasgupta, and J. Glen, 1995, 'Return Behavior in Emerging Stock Markets' The World Bank Economic Review, Vol.9, No.1, pp.131-51.

De Bondt, W., 1991, 'What do Economists know about the Stock Market?' Journal of Portfolio Management, Winter, pp.84-91.

Dickinson, J. P. and K. Muragu, 1994, 'Market Efficiency in Developing Countries: A Case Study of the Nairobi Stock Exchange' Journal of Business Finance and Accounting, Vol.21 No.1, January, pp.133-149.

Divecha, A., J. Drach, and D. Stefek, 1992, 'Emerging Markets: A Quantitative Perspective', Journal of Portfolio Management, Fall, pp.41-56.

El-Erian M. and M. Kumar, 1995, 'Emerging Equity Markets in Middle Eastern Countries', IMF Staff Papers, Vol.42, No.2, pp.313-31.

Errunza, V.R., 1994, 'Emerging Markets: Some New Concepts', Journal of Portfolio Management, Spring, pp.82-87.

Errunza, V., K. Hogan, and M.W. Hung, 1999, 'Can the Gains from International Diversification be Achieved without Trading Abroad?' Journal of Finance, December, Vol. 54, No.6, pp.2075-2107.

Fama E.F, 1970, 'Efficient Capital Markets: A Review of Theory and Empirical Work', Journal of Finance, Vol.25, No.2, pp.383- 417.

Fama E. F. and K. R. French, 1988, 'Permanent and Temporary Components of Stock Prices', Journal of Political Economy, Vol.96, pp.246-273.

French, K.R., and R. Roll, 1986, 'Stock Return Variances: The Arrival of Information and the Reactions of Traders', Journal of Financial Economics, Vol.17, No.3, pp.5-26

Groenewold, N., and M. Ariff, 1998, 'The Effects of De-Regulation on Share-Market Efficiency in the Asia-Pacific', International Economic Journal, Vol.12, No.4, pp.23-47.

Hale, D.D., 1994,'Stock Markets in the New World Order', 1994, Columbia Journal of World Business, Summer, pp.15-28.

Harvey, C., 1993, 'Portfolio Enhancement Using Emerging Markets and Conditioning Information.' In Stijn Claessens and Sudarshan Gooptu, eds., Portfolio Investment in Developing Countries, World Bank Discussion Paper 228, Washington D.C.: World Bank Publications.

Kuczynski, P.P., 1994,'Why Emerging Markets', Columbia Journal of World 
Business, No. 1, 9-13.

International Finance Corporation, 1999, Emerging Markets Factbook and Database, Washington D.C.: International Finance Corporation.

International Finance Corporation, 1997, The IFC Indexes, Methodology, Definitions, and Practices, Washington D.C.: International Finance Corporation.

Levine, R., and S. Zervos, 1998, 'Stock Markets, Banks, and Economic Growth', American Economic Review, Vol.88, No.3, pp.537-58.

Liu, X., H. Song, and P.Romilly, 1997, 'Are Chinese Stock Markets Efficient? A Cointegration and Causality Analysis', Applied Economics Letters, No.4, pp.51115.

Lo, A.W., and A. G. Mackinlay, 1988, 'Stock Market Prices Do Not Follow Random Walks: Evidence from a Simple Specification Test', Review of Financial Studies, Vol.1, No.1, pp.41-66.

Malkiel, B.G., 1996, A Random Walk Down Wall Street, sixth edition. New York: W. W. Norton and Company.

McKinnon, R.I., 1973, Money and Capital in Economic Development, Washington, DC: Brookings Institution.

Mobius, M.J., 1996, Mobius on Emerging Markets, FT Pitman Publishing.

Obstfeld, M., 1994, 'Risk-Taking, Global Diversification, and Growth', American Economic Review, Vol.84, No.5, pp.1310-29.

Olowe, R. A., 1999, 'Weak Form Efficiency of the Nigerian Stock Market: Further Evidence' African Development Review, No.1, pp.54-67.

Snowden, P.N., 1997, 'Enterprise Ownership Constraints and the Role of Equity Markets in Financial Development', Journal of Development Studies, Vol.34, No.1, pp.131-48.

Urrutia, J.L., 1995, 'Tests of Random Walk Efficiency for Latin American Emerging Equity Markets', Journal of Financial Research, Vol.18, No.3, pp.299-313. 